\title{
Article \\ Effects of Temperature on the FT NIR Raman Spectra of Fish Skin Collagen
}

\author{
Maria Połomska ${ }^{1}$, Leszek Kubisz ${ }^{2, *} \mathbb{D}$, Jacek Wolak ${ }^{1}$ and Dorota Hojan-Jezierska ${ }^{3}$ \\ 1 Institute of Molecular Physics, Polish Academy of Sciences, Smoluchowskiego 17, 60-179 Poznań, Poland; \\ polomska@imfpan.pl (M.P.); wolak@ifmpan.poznan.pl (J.W.) \\ 2 Department of Biophysics, Chair of Biophysics, Poznań University of Medical Sciences, Grunwaldzka 6, \\ 61-701 Poznań, Poland \\ 3 Department of of Hearing Healthcare Profession, Chair of Biophysics, Poznań University of Medical Sciences, \\ Grunwaldzka 6, 61-701 Poznań, Poland; djeziers@ump.edu.pl \\ * Correspondence: 1kubisz@ump.edu.pl
}

Citation: Połomska, M.; Kubisz, L: Wolak, J.; Hojan-Jezierska, D. Effects of Temperature on the FT NIR Raman Spectra of Fish Skin Collagen. Appl. Sci. 2021, 11, 8358. https://doi.org/ 10.3390/app11188358

Academic Editor:

Alessandra Biancolillo

Received: 5 August 2021

Accepted: 25 August 2021

Published: 9 September 2021

Publisher's Note: MDPI stays neutral with regard to jurisdictional claims in published maps and institutional affiliations.

Copyright: (c) 2021 by the authors. Licensee MDPI, Basel, Switzerland. This article is an open access article distributed under the terms and conditions of the Creative Commons Attribution (CC BY) license (https:// creativecommons.org/licenses/by/ $4.0 /)$.

\begin{abstract}
The development of regenerative medicine turns attention toward native collagen as a biocompatible material. Particularly interesting is fish skin collagen, which is relatively easy to extract comparing mammalian tissues and free of some pathogens that are dangerous to humans. The paper presents results of IR Raman spectroscopy studies of silver carp (Hypophthalmichthys molitrix) skin collagen. As collagen properties result from its structure and conformation, both sensitive to temperature, FT NIR Raman spectroscopy is an excellent tool to characterize the molecular structure of fish skin collagen, particularly in temperature range typical for the manufacturing processes of biomedical products. Therefore, the Raman spectra were recorded in a temperature range of 300 to $403 \mathrm{~K}$. The analysis of Raman spectra of prepared collagen films, particularly in the range of the bands related to amide I and amide III entities, showed a high content $\alpha$-helix and $\alpha$-helix type molecular organization in fish skin collagen. Additionally, the secondary structure of the studied fish skin collagen is stable up to $\sim 358 \mathrm{~K}$. Heating to $403 \mathrm{~K}$ leads to irreversible changes in the molecular structure of fish skin collagen. It was found that the Raman spectrum of fish skin collagen preheated in this manner becomes similar to the spectrum of the collagen obtained from bovine Achilles tendon, whose secondary structure does not change up to $403 \mathrm{~K}$.
\end{abstract}

Keywords: Raman spectroscopy; fish skin collagen; molecular structure; thermal stability

\section{Introduction}

Collagen is the main constituent of connective tissue in living organisms. Collagen is the basic structural and protective protein, constituting about $30 \%$ of the total protein content and more than $50 \%$ of the skin [1]. Collagen is responsible for the mechanical functions of the skin, its elasticity and tensile strength. It is an important element in the process of healing injuries, representing $50 \%$ of all proteins of a properly healing wound. The uncovering of collagen fibers in damaged tissues triggers a chain of cellular and biochemical reactions initiating the process of blood clotting and healing of tissues. This property of collagen is utilized in the process of homeostasis initiated by means of a collagen sponge applied on the wound [2-4].

The proper process of synthesis and maturation of collagen fibers has a significant influence on the final properties of the scar, its arrangement and strength. Therefore, exogenous collagen, which can additionally convey other substances, such as, e.g., antibiotics, is frequently used to treat wounds [5-8]. Moreover, collagen is a main component of many biomedical hybrid materials [9-11]. Exogenous collagen is applied in tissue engineering and cosmetology. Additionally, some conclusions have been drawn on the correlation of primary fish collagen structure and conformation to film-forming abilities [12]. Medical and cosmetic applications of collagen result from a variety of forms in which it is available 
and its ability to bond with other polymers, both natural and synthetic $[13,14]$. Collagen, including that of animal origin, which is recognized by the organism as its component and not a foreign matter [11,15-18], is characterized by a high degree of biocompatibility [15]. The biocompatibility of collagen is connected with its structure and conformation of molecules. This fact justifies the importance of research into its structure and thermal stability.

Fish collagen, contrary to mammalian collagen, is usually free of some pathogens dangerous to humans. The advantages of fish collagen involve ethical issues related to customs and religions and economic considerations, which are equally important, as fish waste products are a cheap source of collagen [19].

Thus, attention was turned towards fish collagen due to its native structure maintained during the extraction process [20-22]. Collagens originating from different fish species differ in their denaturation temperature. Generally, the lower the temperature of the feeding ground (water) for fish, the lower the denaturation temperature of collagen macromolecules. Particularly interesting, from the point of view of economy, is silver carp (Hypophthalmichthys molitrix), a freshwater fish. The denaturation temperature of silver carp skin collagen is reported to be either $302 \mathrm{~K}$ [1] or $307 \mathrm{~K}[3,23,24]$ depending on the experimental technique. The closer the denaturation temperature of fish skin collagen to mammalian collagen, the higher the potential in supplementing/replacing the skin of land vertebrates as a collagen source and substituting mammalian collagen. Moreover, fish skin collagen extraction is easier and has a higher yield comparing the extraction from mammalian skin $[17,25,26]$.

The basic structural unit of collagen and collagen structure is described elsewhere [27-32]. Collagen polypeptide chains are rich in glycine (Gly), proline (Pro) and 3hdroxyproline (Hyp) (Figure 1), linked together in the characteristic pattern $\mathrm{X}_{\mathrm{Pro}^{-}}$ $\mathrm{Y}_{\text {Hyp }}$-Gly [29].<smiles>NCC(=O)O</smiles>

(a)

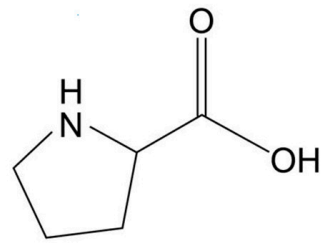

(b)

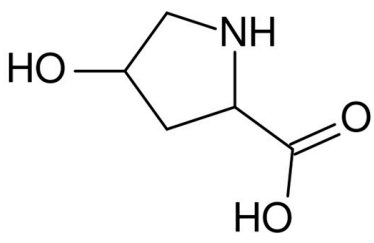

(c)

Figure 1. Schematic model of glycine (a), proline (b) and hydroxyproline (c).

Other amino acids residues, such as alanine, lysosine and tyrosine, may occur in the $X$ or $Y$ locations of the polypeptide chain. In the $\alpha$-chain of fibrous collagen, about $25 \%$ of amino acids are proline and hydroxyproline. They stabilize the triple-helical structure and effectively block internal rotations of collagen chains at these sites [33]. Moreover, hydroxyproline is an important amino acid in maintaining thermal stability of collagen molecules $[34,35]$. The most common secondary structure in collagen type I is the $\alpha$-helix forming a triple helix along with the $\beta$-sheet and irregular conformation [36,37].

The triple helix structure is upheld mainly by hydrogen bonds between the glycine $\mathrm{NH}$ group and carbonyl group $\mathrm{C}=\mathrm{O}$ of residues of another polypeptide chains. Additionally, the triple helix's stability is due to hydrogen bonds between the $\mathrm{C} \alpha \mathrm{H}$ group from glycine and $\mathrm{C}=\mathrm{O}$ and hydrogen bonds with water molecules.

The tree of hydrogen bonds is essential for maintaining the triple helix's stability. On the contrary, its absence leads to a variety of pathological situations [32,38]. The collagen helix is additionally stabilized by van der Waals forces, along with hydrophobic and electrostatic short range interactions [39].

The secondary structure of native collagen can be affected by different factors such as temperature, mechanical forces and chemicals [40-45]. Any deformation in colla- 
gen/protein structure and conformation can be followed by means of Raman spectroscopy, which is particularly useful for this purpose. Any alteration/variation in collagen molecules is noticed in the shift of the position of Raman bands, their intensity and spectral width. The aim of the study was to characterize the secondary structure of silver carp skin collagen in terms of exposure to temperature by means of Fourier transform near IR Raman spectroscopy. NIR Raman spectroscopy appears to be an extremely useful in biomaterials studies. Using laser excitation with wavelength of $1064 \mathrm{~nm}$, beyond the range of electronic absorption, we avoid fluorescence effects. Additionally, lower energy excitation allows us to avoid decomposition (e.g., thermal, photochemical, chemical) of the biomaterials during study. As the reference material, bovine Achilles tendon collagen was used.

\section{Materials and Methods}

The collagen gel used in the experiment was obtained from silver carp (Hypophthalmichthys molitrix) skin (FS collagen) Collagen was purchased from Collagen Active Science Sp. z o. o. Poznan, Poland.The FS collagen obtained by means of the method presented in [21] most probably exhibits a triple helix conformation which is unique to living organisms, which was verified by viscosity measurements and electrophoresis $[3,46,47]$.

Collagen native conformation was determined by means of temperature dependence of viscosity using the Ubbelohde viscometer, in the temperature range of 293-333 K. The denaturation temperature was established as $(306.3 \pm 1.5) \mathrm{K}[3,24,47]$. The molecular weight characteristics found by electrophoresis showed two distinct lines at $\sim 130$ and $\sim 200 \mathrm{kDa}$, related to $\alpha$ - and $\beta$-chains, respectively [44]. The amino acid content can be found elsewhere [46].

Collagen gel was dissolved in water and the acquired $10 \%$ solution was poured into a Petri dish and dried at room temperature. Obtained films were used in further studies. Raman spectra were recorded with a Bruker IFS66FT IR spectrometer equipped with an FRA106 Raman module. The samples were excited by a diode pumped Nd:YAG laser operated at $\lambda=1064 \mathrm{~nm}$ with output power of $\sim 50 \mathrm{~mW}$. Raman spectra were measured in the $303-403 \mathrm{~K}$ range of temperature using a Linkam cooling-heating stage in $180^{\circ}$ geometry. The temperature range of approximately $300-400 \mathrm{~K}$ covers the temperature range expected in many biomedical applications as well as collagen stability against temperature [48].

Moreover, the application of IR radiation permitted us to avoid any effect of UV radiation on collagen structure [49].

The molecular structure and the temperature effects on the secondary structure of fish skin (FS) collagen were compared with bovine Achilles tendon (BAT) collagen purchased from Sigma-Aldrich, Poland. Its amino acid composition can be found in [50].

\section{Results and Discussion}

\subsection{Raman Spectra of FS and BAT Collagen Measured at Room Temperature}

The Raman spectra of FS and BAT collagen recorded at $303 \mathrm{~K}$ are presented in Figure 2.

Table 1 presents the assignment of the Raman bands for FS and BAT type collagen at room temperature. To assign the Raman bands of samples used in this study, the results of vibrational studies of different samples containing different kinds of collagen as well as proline, hydroxyproline and glycine separately were utilized [35-37,45,51-59].

In the Raman spectra of collagen, one can distinguish four principal frequency ranges: the first at $200-600 \mathrm{~cm}^{-1}$, assigned to the vibrations of the triple helix [44,59], the second at $800-1200 \mathrm{~cm}^{-1}$, assigned mainly to the vibration of proline and hydroxyproline as well as secondary structure of collagen, and the third at $1200-1750 \mathrm{~cm}^{-1}$, where the bands related to amide I and amide III vibrations were observed. The fourth frequency range from 2800 to $3200 \mathrm{~cm}^{-1}$ presents the band related to $\mathrm{CH}_{2}$ group vibrations. 

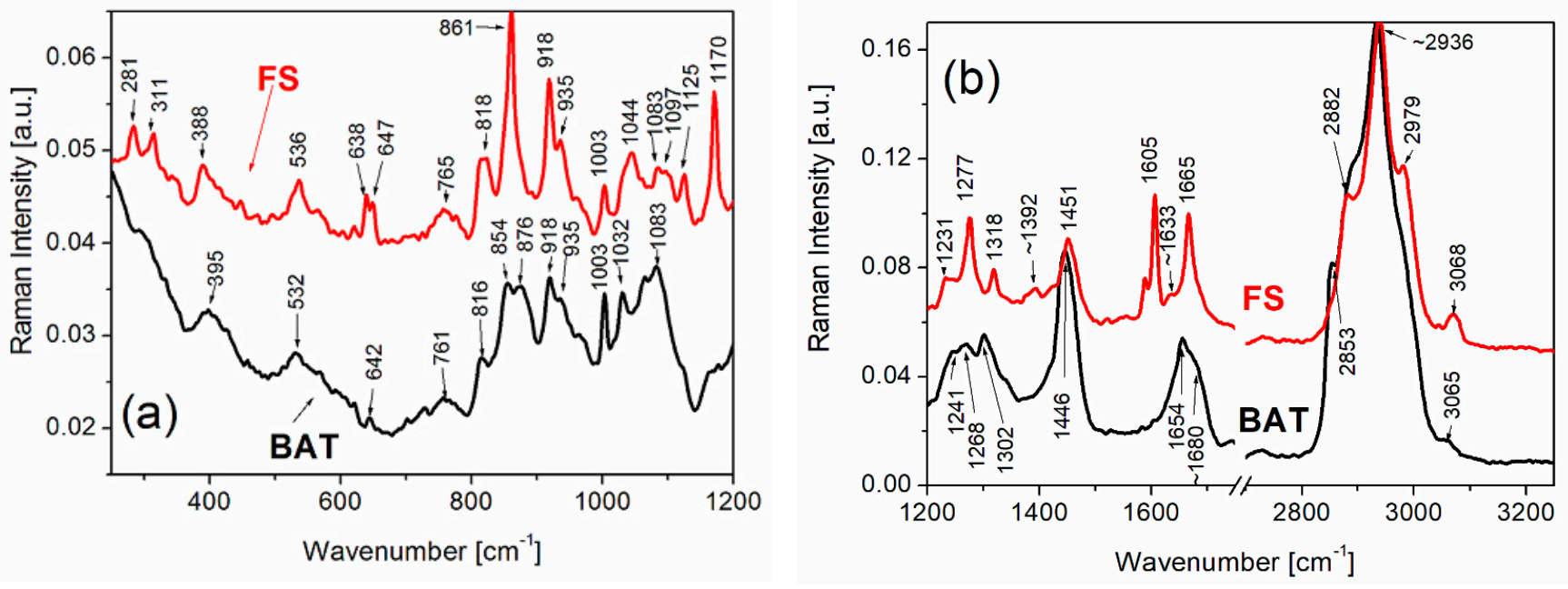

Figure 2. Raman spectra of FS and BAT types of collagen in the range from 250 to $1200 \mathrm{~cm}^{-1}$ (a), in the range of amide I, amide III and the range of $\mathrm{CH}_{2}$ vibrations (b). Raman spectra were recorded at $303 \mathrm{~K}$.

Table 1. Assignment of the Raman bands of FS and BAT types of collagen at room temperature.

\begin{tabular}{|c|c|c|c|}
\hline $\begin{array}{l}\text { FS } \\
\text { Band Position } / \mathrm{cm}^{-1}\end{array}$ & $\begin{array}{l}\text { BAT } \\
\text { Band Position } / \mathrm{cm}^{-1}\end{array}$ & Assignment & Assignment \\
\hline $282 \mathrm{w}$ & $292 \mathrm{vw}$ & & 3-helix \\
\hline $314 \mathrm{w}$ & $307 \mathrm{vw}$ & & 3-helix \\
\hline 388 vw & $396 \mathrm{w}$ & & \\
\hline $535 \mathrm{w}$ & $530 \mathrm{w}$ & $\delta(\mathrm{CCN})$ & \\
\hline $639 w$ & $644 \mathrm{vw}$ & $\delta, \omega\left(\mathrm{COO}^{-}\right)$ & \\
\hline \multicolumn{4}{|l|}{$649 w$} \\
\hline $760 \mathrm{w}$ & $760 w$ & $v(\mathrm{CCO})$ & \\
\hline $813 \mathrm{w}$ & $815 \mathrm{w}$ & $v(\mathrm{COC}), v(\mathrm{CC})$ & \\
\hline \multicolumn{4}{|l|}{$822 \mathrm{w}$} \\
\hline 850 wsh & $854 \mathrm{~m}$ & $v(\mathrm{COC}), v(\mathrm{CC})$ & Pro \\
\hline \multicolumn{4}{|l|}{$861 \mathrm{~m}$} \\
\hline 870 wsh & $874 \mathrm{~m}$ & $v(C C)$ & Hyp \\
\hline $918 \mathrm{~m}$ & $918 \mathrm{~m}$ & $v\left(\mathrm{C}-\mathrm{COO}^{-}\right)$ & $\alpha$-helix \\
\hline $935 \mathrm{~m}$ & $935 \mathrm{~m}$ & $v(\mathrm{CC})$ & $\alpha$-helix \\
\hline $962 \mathrm{w}$ & $964 \mathrm{w}$ & & \\
\hline $975 \mathrm{w}$ & 974 & & \\
\hline $1003 \mathrm{w}$ & $1002 \mathrm{~m}$ & $v(C C)$ aromatic ring & $\begin{array}{l}\text { phenylalanine, } \\
\text { tyrosine, tryptophane }\end{array}$ \\
\hline 1029 wsh & $1030 \mathrm{~m}$ & $v(\mathrm{CCN})$ & phenylalanine \\
\hline $1045 \mathrm{w}$ & 1042 wsh & & $\beta$-sheet \\
\hline $1060 \mathrm{sh}$ & $1064 \mathrm{~m}$ & $\omega\left(\mathrm{CH}_{2}\right)$ & $\beta$-sheet \\
\hline $1085 \mathrm{w}$ & $1082 \mathrm{~m}$ & $v(\mathrm{CN})$ & \\
\hline $1096 \mathrm{w}$ & $1096 \mathrm{msh}$ & $v(\mathrm{CN})$ & \\
\hline 1124 & $1123 \mathrm{msh}$ & & \\
\hline
\end{tabular}


Table 1. Cont.

\begin{tabular}{|c|c|c|c|}
\hline $\begin{array}{l}\text { FS } \\
\text { Band Position } / \mathrm{cm}^{-1}\end{array}$ & $\begin{array}{l}\text { BAT } \\
\text { Band Position } / \mathrm{cm}^{-1}\end{array}$ & Assignment & Assignment \\
\hline $1171 \mathrm{~m}$ & & $\begin{array}{l}\delta(\mathrm{CH}), v(\mathrm{CCC}) \\
\text { out-of-phase }\end{array}$ & tyrosine \\
\hline \multirow[t]{2}{*}{$1233 \mathrm{~m}$} & & $v(\mathrm{CN}), \delta(\mathrm{CH}), \delta(\mathrm{NH})$ & \\
\hline & $1245 \mathrm{ssh}$ & $\delta(\mathrm{NH})$ & disordered (amide III) \\
\hline \multirow[t]{2}{*}{$1275 \mathrm{~m}$} & $1270 \mathrm{~s}$ & $\delta(\mathrm{NH})$ & $\alpha$-helix (amide III) \\
\hline & $1301 \mathrm{~s}$ & & \\
\hline $1318 \mathrm{w}$ & $1318 \mathrm{sh}$ & $\gamma\left(\mathrm{CH}_{2}\right)$ & \\
\hline 1340 wsh & $1340 \mathrm{msh}$ & $\delta\left(\mathrm{CH}_{2}\right)$ & \\
\hline $1391 \mathrm{vw}$ & & $\delta\left(\mathrm{CH}_{2}\right), v\left(\mathrm{COO}^{-}\right)$ & \\
\hline 1449 s & $1445 \mathrm{~s}$ & $\delta\left(\mathrm{CH}_{2}\right)$ & \\
\hline 1588 wsh & $1583 \mathrm{~s}$ & $v(\mathrm{CCH})$ aromatic ring & \\
\hline 1607 s & 1604 & $v(\mathrm{CCH})$ aromatic ring & \\
\hline 1633 wsh & & $v(\mathrm{C}=\mathrm{O})$ & 3-helix \\
\hline \multirow[t]{3}{*}{$1666 \mathrm{~s}$} & $1656 \mathrm{~s}$ & $v(\mathrm{C}=\mathrm{O})$ & $\alpha$-helix (amide I) \\
\hline & $1671 \mathrm{~s}$ & & $\beta$-sheet (amide I) \\
\hline & 1680 & & disordered (amide I) \\
\hline \multirow[t]{2}{*}{$2861 \mathrm{ssh}$} & $2853 \mathrm{ssh}$ & $v_{\text {as }}\left(\mathrm{CH}_{2}\right)$ & \\
\hline & $2888 \mathrm{ssh}$ & & \\
\hline 2938 vs & 2934 vs & $v_{\mathrm{s}}\left(\mathrm{CH}_{2}\right)$ & \\
\hline \multicolumn{4}{|l|}{$2982 \mathrm{ssh}$} \\
\hline $3071 \mathrm{w}$ & & $v(\mathrm{C}=\mathrm{CH})$ & \\
\hline
\end{tabular}

Abbreviations: s: strong, m: medium, w: weak, v: very, sh: shoulder, $v$ : stretching, $\delta$ : in plane bending symmetric, $\gamma$ : in plane bending antisymmetric, $\omega$ : out of plane bending symmetric.

The Raman lines at 282 and $314 \mathrm{~cm}^{-1}$ are clearly visible for FS collagen, whereas similar lines at 292 and $307 \mathrm{~cm}^{-1}$ for BAT collagen are broadened and exhibit low intensities. Some authors $[41,53]$ assign the lines in the range 200 to $400 \mathrm{~cm}^{-1}$ to the vibrations related to a triple helicity of the collagen. A significant difference between FS collagen and BAT collagen is observed in the frequency range $830-900 \mathrm{~cm}^{-1}$. The doublet of lines at 854 and $874 \mathrm{~cm}^{-1}$ for BAT collagen is assigned to $\delta(\mathrm{CCH})$ aromatic and $v(\mathrm{CC})$ proline and hydroxyproline vibrations, respectively. In the case of FS collagen, one intense band with weak shoulders is observed at $861 \mathrm{~cm}^{-1}$. After deconvolution of the band, the shoulders occur at $\sim 854 \mathrm{~cm}^{-1}$ and $\sim 870 \mathrm{~cm}^{-1}$. The band centered at $861 \mathrm{~cm}^{-1}$ may be assigned to the vibrations related to tyrosine. The shoulders with low intensities at $\sim 854$ and $\sim 870 \mathrm{~cm}^{-1}$ may be related to the vibrations of proline and hydroxyproline. The remaining Raman bands occurring in this frequency range appear in similar positions and are characterized by similar intensities, both for BAT and FS.

As was discussed in the earlier papers [42,43], the lines related to C-C stretching vibrations in the range 890 to $1060 \mathrm{~cm}^{-1}$ may also characterize the secondary structure of collagen. The lines at 918 and $936 \mathrm{~cm}^{-1}$ are characteristic of $\alpha$-helices and the lines in the range from 1020 to $1060 \mathrm{~cm}^{-1}$ are related to $\beta$-sheet structure. A gradual loss of these structures leads to a broadening and weakening in the intensity of the bands which are assigned to these vibrations [43]. The Raman band positions of these vibrations are similar for FS and BAT types of collagen. There are, however, some differences in the ratio of the band intensities. The band at $918 \mathrm{~cm}^{-1}$ for FS exhibits higher intensity compared to the same line for BAT. It could also be related to a higher content of the $\alpha$-chain conformation 
in FS. Another difference between the Raman spectra of BAT and FS collagen appears for the line at $1171 \mathrm{~cm}^{-1}$, which is assigned to $v(C C C)$ out-of-phase vibration related to the vibrations of tyrosine residue. The line, which is sharp and intense for FS collagen, has very low intensity for BAT.

The vibrations of amide I and amide III are most sensitive to changes in the conformation of the secondary structures of collagen. The vibrations related to these molecular groups appear in the spectral range from 1200-1750 cm ${ }^{-1}$. The bands between 1200 and $1350 \mathrm{~cm}^{-1}$ are assigned to the vibrations of amide III, where the modes related to C-N stretching and N-H in-plane bending vibrations of the peptide bond as well as contributions from $\mathrm{C}-\mathrm{C}$ stretching and $\mathrm{C}=\mathrm{O}$ in-plane bending vibrations exist. The bands located in the range around $1260-1300 \mathrm{~cm}^{-1}$ may be responsible for the $\alpha$-helix conformation, whereas the bands between 1240 and $1250 \mathrm{~cm}^{-1}$ could be related to both random coil and $\beta$-sheet structures [43].

The bands revealed in the range $\sim 1600-1680 \mathrm{~cm}^{-1}$ are mainly assigned to the stretching vibrations $\mathrm{C}=\mathrm{O}$ of the peptide bond and the bending vibrations of the $\mathrm{N}-\mathrm{H}$ group. The bands of amide I can characterize the hydrogen bonds of diverse structures. These diverse hydrogen bonds in the polypeptide chain are responsible for the type of the secondary structure of the protein that is an $\alpha$-helix arranged in a spiral which is stabilized by hydrogen bonds between the oxygen of the $\mathrm{C}=\mathrm{O}$ group of one amino acid and nitrogen of a second amino acid located four positions away. The $\beta$-sheet is conformation which should contain a minimum of two strands and is stabilized by hydrogen bonds between the $\mathrm{C}=\mathrm{O}$ group of one strand and the $\mathrm{NH}$ group of the another strand as well as disordered structures. The Raman band assigned to amide I of FS collagen consists of a narrow line at $\sim 1666 \mathrm{~cm}^{-1}$ and a shoulder at $\sim 1633 \mathrm{~cm}^{-1}$. On the basis of the previous Raman studies on collagen [37,57], this band can be attributed to a significant content of $\alpha$-helix structures. In the case of BAT collagen, a wide band of amide I having the local maximum at $\sim 1655 \mathrm{~cm}^{-1}$, along with extra shoulders at $\sim 1671 \mathrm{~cm}^{-1}$ and $\sim 1680 \mathrm{~cm}^{-1}$, was observed. Such a wide, complex band related to amide I of BAT collagen can suggest that it contains $\alpha$-helix structures as well as $\beta$-sheet and other disordered structures. The most intense bands presented in the range $2800-3200 \mathrm{~cm}^{-1}$ belong to the stretching vibrations of the $\mathrm{CH}_{2}$ group and are similar for both FS and BAT types of collagen.

\subsection{Temperature Effect on the FS Collagen}

Temperature studies of Raman spectra of FS and BAT collagen were carried out in the temperature range from $303 \mathrm{~K}$ to $403 \mathrm{~K}$. In Figure 3a,b, temperature changes of FS collagen and BAT collagen Raman spectra are presented, respectively. Raman spectra of FS collagen do not change up to $\mathrm{T} \cong 353 \mathrm{~K}$, and above $353 \mathrm{~K}$ Raman spectra undergo irreversible change. The most significant changes are observed for the lines at 860, 918, 935, $1171 \mathrm{~cm}^{-1}$ and for the bands related to amide I and amide III vibrations. The sharp line at $860 \mathrm{~cm}^{-1}$ in the spectrum at $303 \mathrm{~K}$, assigned to tyrosine, is significantly less intense at $403 \mathrm{~K}$ (Figure 4a). The doublet of lines at 918 and $935 \mathrm{~cm}^{-1}$, assigned to $\alpha$-helix conformation, shows a considerable decrease in their intensities at $403 \mathrm{~K}$. The most significant changes in high temperature are observed for the bands related to both amide I and amide III vibrations. A substantial shift of the band at $1274 \mathrm{~cm}^{-1}$ to $\sim 1270 \mathrm{~cm}^{-1}$ (Figure 5a) assigned to the $\alpha$-helix may indicate its considerable decrease and an increase in the content of both $\beta$-sheets and the disordered part of the polypeptide chain. On the other hand, in the part of the Raman spectrum related to the vibrations of amide I (Figure 5c), one can observe a shift of a narrow band centered at $1666 \mathrm{~cm}^{-1}$ to a higher frequency at $\sim 1670 \mathrm{~cm}^{-1}$. Moreover, a decreasing intensity of the line suggests a reduction in the content of $\alpha$-helix conformation and an increase in the content of the $\beta$-sheet phase. We can also observe a significant widening of Raman bands, indicating increased structural disorder (Figure 5b). 

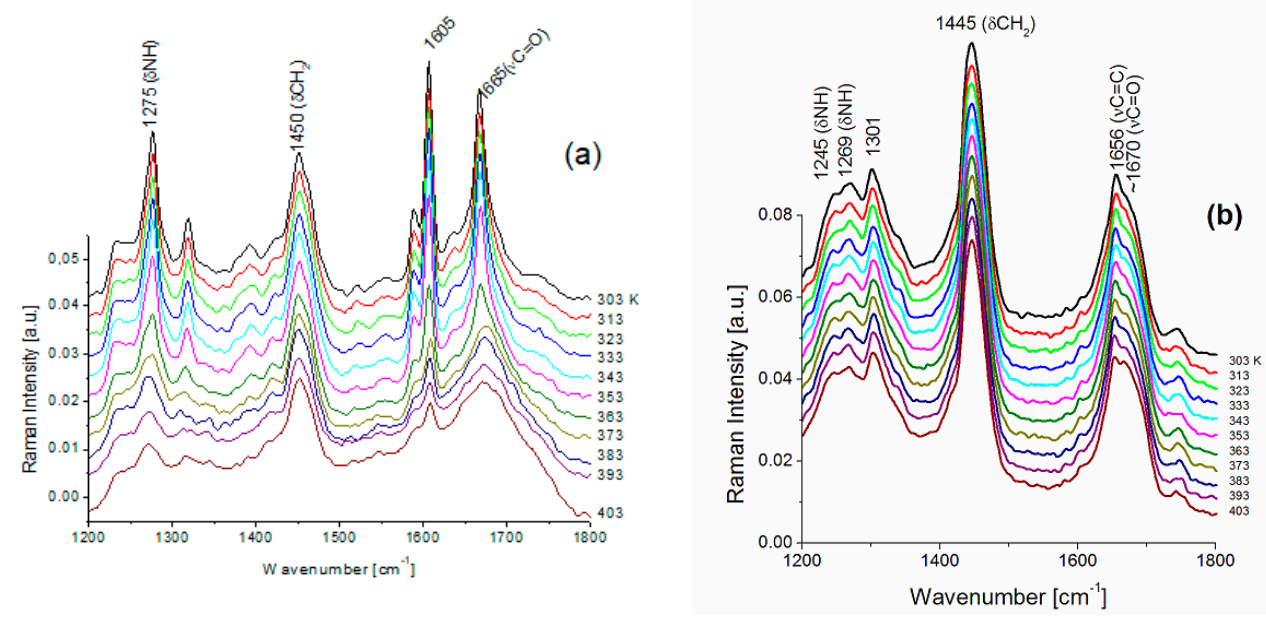

Figure 3. Temperature changes of Raman spectra for FS collagen (a) and BAT collagen (b) in the frequency range of amide III and amide I vibrations.
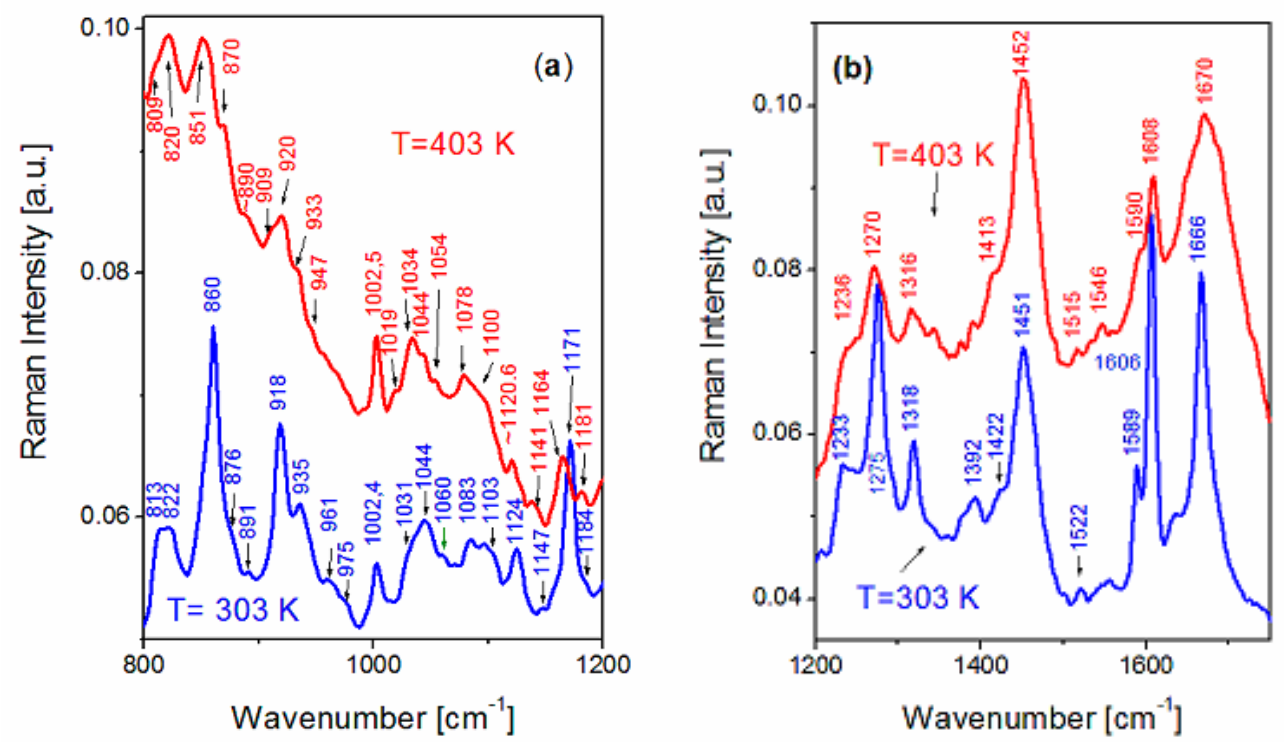

Figure 4. Comparison of Raman spectra of FS collagen measured at $303 \mathrm{~K}$ and $403 \mathrm{~K}$ in the frequency ranges $800-1200 \mathrm{~cm}^{-1}$ (a) and $1200-1750 \mathrm{~cm}^{-1}$ (b). 

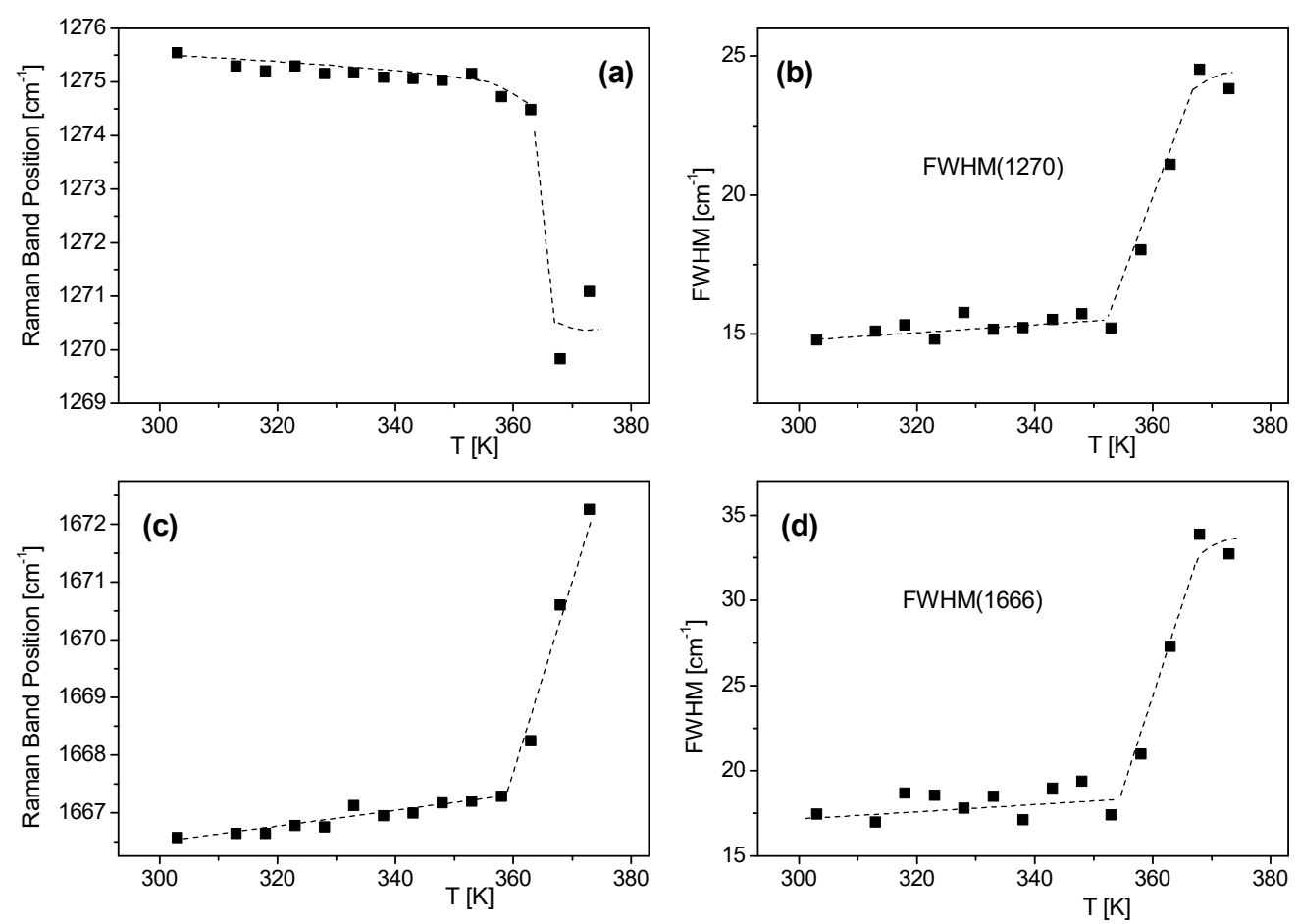

Figure 5. Temperature dependence of the Raman band position of FS related to amide III vibration (a) and its spectral width (b), amide I vibration (c) and its spectral width (d). The lines are guides for the eye.

To conclude, the temperature studies of the Raman spectra of FS collagen revealed conspicuous changes occurring in the $\sim 358 \mathrm{~K}$ to $\sim 363 \mathrm{~K}$ temperature range. Heating of FS collagen to $403 \mathrm{~K}$ causes irreversible changes in its secondary structure.

Comparing the Raman spectra of BAT and FS collagen measured at $403 \mathrm{~K}$ (Figure 6), one can see their striking similarity, whereas at room temperature considerable differences can be observed (see Figure 2).

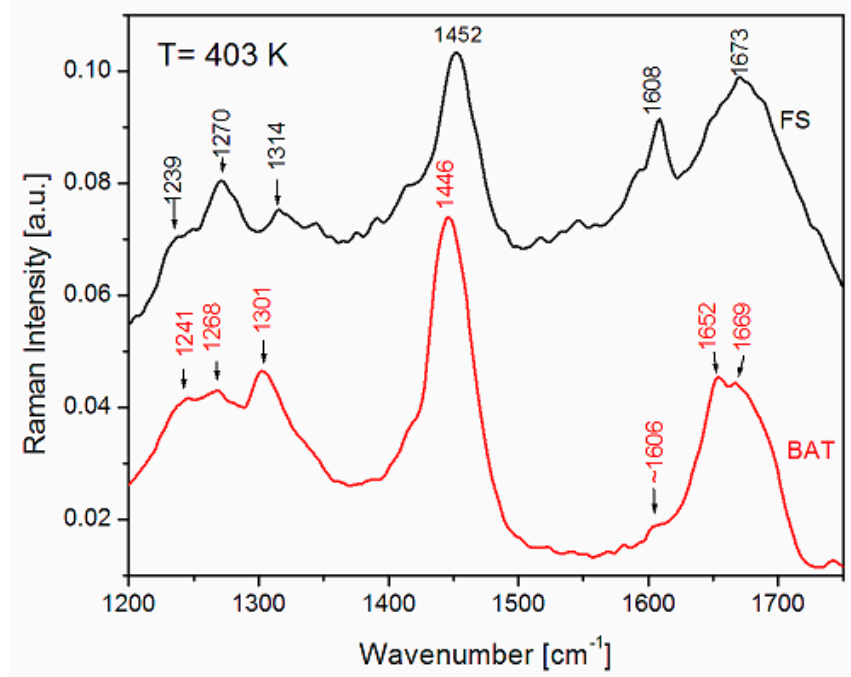

Figure 6. Comparison of Raman spectra of FS and BAT collagen in the range of amide I and amide III vibrations measured at $403 \mathrm{~K}$.

Temperature studies of Raman spectra changes in BAT collagen showed that the character of Raman spectra does not undergo any change in the temperature range from $300 \mathrm{~K}$ to $403 \mathrm{~K}$ (Figures $3 \mathrm{~b}$ and 7). Additionally, the Raman band positions change linearly with increasing temperature (Figure 8), not exhibiting any anomalous behavior. 


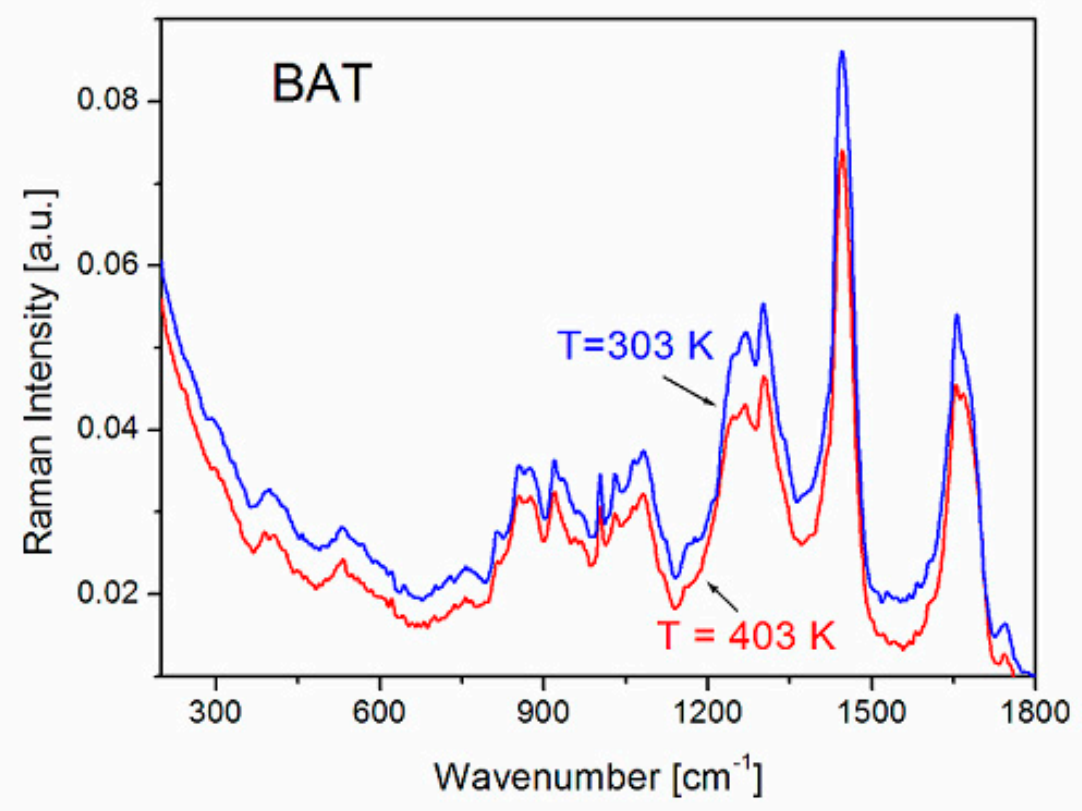

Figure 7. Comparison of the Raman spectra of BAT collagen measured at $303 \mathrm{~K}$ and $403 \mathrm{~K}$.

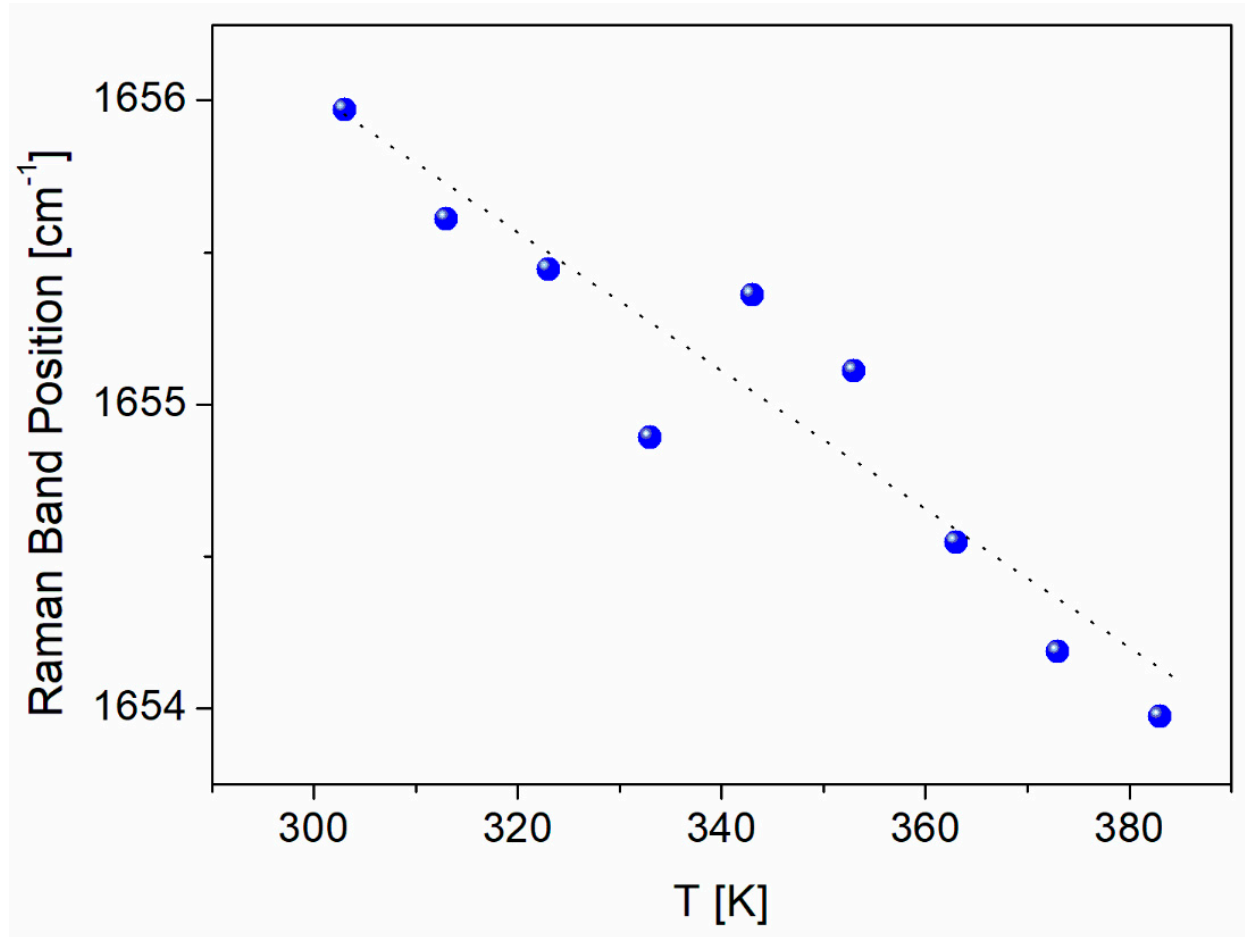

Figure 8. Temperature dependence of the Raman band position of BAT collagen related to amide I vibration. The line is a guide for the eye.

Analyzing the thermal changes in the amide groups for both FS and BAT types of collagen, we compare the Raman intensity ratios of the most intense bands at $\sim 1270 \mathrm{~cm}^{-1}$ (precisely $\sim 1275 \mathrm{~cm}^{-1}$ for FS and $\sim 1270 \mathrm{~cm}^{-1}$ for BAT) for amide III and $\sim 1660 \mathrm{~cm}^{-1}$ (1666 cm $\mathrm{cm}^{-1}$ for FS and $\sim 1656 \mathrm{~cm}^{-1}$ for BAT) for amide I with the intensity of the band at $\sim 1450 \mathrm{~cm}^{-1}$. The band at $\sim 1450 \mathrm{~cm}^{-1}$ is related to the $\mathrm{CH}_{2}$ bending vibration, which is practically insensitive to the secondary structure. Table 2 presents the Raman band intensity ratios at $303 \mathrm{~K}$ and $403 \mathrm{~K}$ for both types of collagen. 
Table 2. Raman intensity ratios of amide I and amide III bands to Raman intensity of $\mathrm{CH}_{2}$ band for FS and BAT collagens.

\begin{tabular}{ccccc}
\hline & $\begin{array}{c}\text { Amide I } \\
\mathbf{I}_{(\sim \mathbf{1 6 0 0})} / \mathbf{I}_{(\sim \mathbf{1 4 5 0})}\end{array}$ & $\begin{array}{c}\text { Amide III } \\
\mathbf{I}_{(\sim \mathbf{1 2 7 0})} / \mathbf{I}_{(\sim \mathbf{1 4 5 0})}\end{array}$ & $\begin{array}{c}\text { Amide I } \\
\mathbf{I}_{(\sim \mathbf{1 6 0 0})} / \mathbf{I}_{(\sim \mathbf{1 4 5 0})}\end{array}$ & $\begin{array}{c}\text { Amide III } \\
\mathbf{I}_{(\sim \mathbf{1 2 7 0})} / \mathbf{I}_{(\sim \mathbf{1 4 5 0})}\end{array}$ \\
\hline Temperature & \multicolumn{2}{c}{$303 \mathrm{~K}$} & \multicolumn{2}{c}{$403 \mathrm{~K}$} \\
\hline FS & 1.56 & 1.16 & 0.65 & 0.49 \\
\hline BAT & 0.62 & 0.39 & 0.63 & 0.36 \\
\hline
\end{tabular}

As shown earlier, the Raman spectra of BAT collagen do not undergo any change up to $403 \mathrm{~K}$. The intensity ratios of the Raman bands characteristic of $\alpha$-helix frequencies of amide I and amide III to the $\mathrm{CH}_{2}$ bending band presented in Table 2 are nearly the same for $303 \mathrm{~K}$ and $403 \mathrm{~K}$. However, in the case of FS collagen, these dependences change considerably. At $303 \mathrm{~K}$, the intensity ratios of the bands assigned to the vibrations of $\alpha$-helix conformation are nearly three times higher for amide I and almost four times higher for amide III, compared with BAT collagen, while at $403 \mathrm{~K}$ the values are comparable.

\section{Conclusions}

The analysis of the recorded Raman spectra of fish skin collagen at room temperature revealed a relatively high content of $\alpha$-helix structure in a film made of collagen gel. The high intensity of the bands of amide I and amide III at $\sim 1666 \mathrm{~cm}^{-1}$ and $\sim 1274 \mathrm{~cm}^{-1}$, respectively, suggested a significant content of $\alpha$-helix structure in the studied material. The intensities of the above bands were much higher than the intensities of the corresponding bands for the BAT collagen.

The effect of temperature on the Raman spectra of FS collagen was insignificant up to the temperature $358 \mathrm{~K}$. Above this temperature, the content of $\alpha$-helix structure was reduced and beneficial to the $\beta$-sheet structure and other disordered structures. From this temperature, the Raman spectrum of FS collagen resembled the Raman spectrum of BAT collagen. Therefore, one could conclude that FS collagen is thermally stable up to $\sim 358 \mathrm{~K}$ and maintained its native structure. Opposite to fish skin collagen, studies on temperature effects on Raman spectra of BAT collagen did not reveal any change in the secondary structure up to temperature $403 \mathrm{~K}$.

These results coincide with the results of studying the thermal stability of FS collagen foil by means of the DSC method presented in [40,41]. It was shown in these works that the thermal stability temperature of the foil collagen from swim bladders obtained from a variety of fish is 338.9-347.8K [60], whereas for the collagen films from silver carp skin it is $350 \mathrm{~K}$ or $352 \mathrm{~K}[61,62]$. This indicates an ideal agreement of denaturation temperature of collagen foil determined by means of the DSC method with the temperature at which the changes in the secondary structure of FS collagen revealed by Raman spectroscopy were observed in the present work.

A high content of $\alpha$-helix structure in fish skin collagen suggests its high biocompatibility and a variety of possible applications in regenerative medicine and cosmetology.

Author Contributions: Authors equally contributed to this work. All authors have read and agreed to the published version of the manuscript.

Funding: The experiment was supported by the National Centre for Research and Development within the Framework of Applied Research Programme, PBS3/B7/28/2015.

Institutional Review Board Statement: Not applicable.

Conflicts of Interest: The authors declare no conflict of interest. 


\section{References}

1. de Melo Oliveira, V.; Assis, C.R.D.; Costa, B.D.A.M.; de Araujo Neri, R.C.; Monte, F.T.D.; da Costa Vasconcelos, H.M.S.; Franca, R.C.P.; Santos, J.F.; Bezerra, R.d.S.; Porto, A.L.F. Physical, biochemical, densitometric and spectroscopic techniques for characterization collagen from alternative sources: A review based on the sustainable valorization of aquatic by-products. J. Mol. Struct. 2021, 1224, 129023. [CrossRef]

2. Manon-Jensen, T.; Kjeld, N.G.; Karsdal, M.A. Collagen-mediated hemostasis. J. Thromb. Haemost. 2016, 14, 438-448. [CrossRef]

3. Kubisz, L.; Hojan-Jezierska, D.; Szewczyk, M.; Majewska, A.; Kawałkiewicz, W.; Pankowski, E.; Janus, M.; Cwajda-Białasik, J.; Mościcka, P.; Jawień, A. In vivo electrical impedance measurement in human skin assessment. Pure Appl. Chem. 2019, 91, 1481-1491. [CrossRef]

4. Park, K.H.; Kwon, J.B.; Park, J.H.; Shin, J.C.; Han, S.H.; Lee, J.W. Collagen dressing in the trement of diabetic foot ulcer: A prospective, randomized, placebo-controlled, single-center study. Diabetes Res. Clin. Pract. 2020, 156, 107861. [CrossRef] [PubMed]

5. Liu, X.; Zheng, C.; Luo, X.; Wang, X.; Jiang, H. Recent advances of collagen-based biomaterials: Multi-hierarchical structure, modification and biomedical applications. Mater. Sci. Eng. 2019, 99, 1509-1522. [CrossRef]

6. Chong, C.; Wang, Y.; Fathi, A.; Parungao, R.; Maitz, P.K.; Li, Z. Skin wound repair: Results of a pre-clinical study to evaluate electropsun collagen-elastin-PCL scaffolds as dermal substitutes. Burns 2019, 45, 1639-1648. [CrossRef] [PubMed]

7. Lukáč, P.; Hartinger, J.M.; Mlček, M.; Popková, M.; Suchý, T.; Šupová, M.; Zavora, L.; Adamkova, V.; Benakova, H.; Slanar, O. A novel gentamicin-releasing wound dressing prepared from freshwater fish Cyprinus carpio collagen cross-linked with carbodiimide. J. Bioact. Compat. Polym. 2019, 34, 246-262. [CrossRef]

8. Cwajda-Białasik, J.; Mościcka, P.; Szewczyk, M.T.; Hojan-Jezierska, D.; Kawałkiewicz, W.; Majewska, A.; Janus-Kubiak, M.; Kubisz, L.; Jawień, A. Venous leg ulcers treated with fish collagen gelin a 12-week randomized single-centre study. Adv. Dermatol. Allergol. 2021, 38, 1-9. [CrossRef]

9. Lotz, C.; Schmid, F.F.; Oechsle, E.; Monaghan, M.G.; Walles, H.; Groeber-Becker, F. Cross-linked collagen hydrogel matrix resisting contraction to facilitate full-thickness skin equivalents. ACS Appl. Mater. Interfaces 2017, 9, 204. [CrossRef]

10. Miri, A.K.; Muja, N.; Kamranpour, N.O.; Lepry, W.C.; Boccaccini, A.R.; Clarke, S.A.; Nazhat, S.N. Ectopic bone formation in rapidly fabricated acellular injectable dense collagen-bioglass hybrid scaffolds via gel aspiration-ejection. Biomaterials 2016, 85, 128-141. [CrossRef]

11. Sionkowska, A.; Skrzyński, S.; Śmiechowski, K.; Kołodziejczak, A. The review of versatile application of collagen. Polym. Adv. Technol. 2017, 28, 4-9. [CrossRef]

12. Chen, L.T.S.; Su, W.; Weng, W.; Osako, K.; Tanaka, M. Physicochemical properties and film-forming ability of fish skin collagen extracted from different freshwater species. Process. Biochem. 2015, 50, 148-155.

13. Bardakova, K.N.; Grebenik, E.A.; Minaev, N.V.; Churbanov, S.N.; Moldagazyeva, Z.; Krupinov, G.E.; Kostjuk, S.V.; Timasheva, P.S. Tailoring the collagen film structural properties via direct laser crosslinking of star-shaped polylactide for robust scaffold formation. Mater. Sci. Eng. 2020, 107, 110300. [CrossRef] [PubMed]

14. Szumała, P.; Jungnickel, C.; Kozłowska-Tylingo, K.; Jacyna, B.; Cal, K. Transdermal transport of collagen and hyaluronic acid using water in oil microemulsion. Int. J. Pharm. 2019, 572, 118738. [CrossRef] [PubMed]

15. An, B.; Lin, Y.S.; Brodsky, B. Collagen interactions: Drug design and delivery. Adv. drug Deliv. Rev. 2016, 97, 69-84. [CrossRef]

16. Chowdhury, S.R.; Busra, M.F.M.; Lokanathan, Y.; Ng, M.H.; Law, J.X.; Cletus, U.C.; Idrus, R.B.H. Collagen type I: A versatile biomaterial. Nov. Biomater. Regen. Med. 2018, 1077, 389-414.

17. Blidi, E.; del Omari, N.; Balahbib, A.; Ghchime, R.; del Menyiy, N.; Ibrahimi, A.; Kaddour, K.B.; Bouyahya, A.; Chokairi, O.; Barkiyou, M. Extraction Methods, Characterization and Biomedical Applications of Collagen: A Review. Biointerface Res. Appl. Chem. 2021, 11, 13587-13613. [CrossRef]

18. Salvatorea, L.; Gallob, N.; Natalia, M.L.; Campaa, L.; Lunettib, P.; Madaghieleb, M.; Blasib, F.S.; Corallob, A.; Capobiancoc, L.; Sannino, A. Marine collagen and its derivatives: Versatile and sustainable bio-resources for healthcare. Mater. Sci. Eng. 2020, 113, 110963. [CrossRef]

19. Rahman, A. Collagen of Extracellular Matrix from Marine Invertebrates and Its Medical Applications. Mar. Drugs 2018, 16, 118. [CrossRef]

20. Jayaraman, A.; Price, C.; Sullivan, M.O.; Kiick, K.L. Collagen-Peptide-Based Drug Delivery Strategies. Technol. Innov. 2020, 21, 1-20. [CrossRef]

21. Przybylski, J.E.; Siemaszko-Przybylska, K. Patent 190737 Patent Office, Poland. 2002.

22. Sun, J.; Zhang, J.; Zhao, D.; Xue, C.; Liu, Z.; Mao, X. Characterization of turbot (scophthalmus maximus) skin and the extracted acid-soluble collagen. J. Ocean Univ. China 2019, 18, 687-692. [CrossRef]

23. Rodziewicz-Motowidło, S.; Śladewska, A.; Mulkiewicz, E.; Kołodziejczyk, A.; Aleksandrowicz, A.; Miszkiewicz, J.; Stepnowski, P. Isolation and characterization of a thermally stable collagen preparation from the outer skin of the silver carp Hypophthalmichthys molitrix. Aquaculture 2008, 285, 130-134. [CrossRef]

24. Janus, M.; Pankowski, E.; Hojan-Jezierska, D.; Kubisz, L. Study of fish skin collagen by viscosimetric method. In Proceedings of the 24th Annual World Forum on Advanced Materials, Poznań, Poland, 9-13 May 2016; pp. 76-77.

25. Yunoki, S.; Suzuki, T.; Takai, M. Stabilization of low denaturation temperature collagen from fish by physical cross-linking methods. J. Biosci. Bioeng. 2003, 96, 575-577. [CrossRef] 
26. Jafari, H.; Lista, A.; Siekapen, M.M.; Ghaffari-Bohlouli, P.; Nie, L.; Alimoradi, H.; Shavandi, A. Fish Collagen: Extraction, Characterization, and Applications for Biomaterials Engineering. Polymers 2020, 12, 2230. [CrossRef] [PubMed]

27. Bella, J.; Eaton, M.; Brodsky, B.; Berman, H.M. Crystal and molecular structure of a collagen like peptide at $1.9 \AA$ resolution. Science 1994, 266, 75-81. [CrossRef] [PubMed]

28. Bella, J.; Berman, H.M. Crystallographic evidence for $\mathrm{C} \alpha-\mathrm{H} \cdots \mathrm{O}=\mathrm{C}$ hydrogen bonds in a collagen triple helix. J. Mol. Biol. 1996, 264, 734-742. [CrossRef] [PubMed]

29. Okuyama, K.; Xu, X.; Iguchi, M.; Noguchi, K. Revision of collagen structure. Biopolymers 2005, 84, 181-191. [CrossRef]

30. Gelse, K.; Pöschl, E.; Aigner, T. Collagen-structure, function, and biosynthesis. Adv. Drug Del. Rev. 2003, 55, 1531-1546. [CrossRef]

31. Shoulders, M.D.; Raines, R.T. Collagen structure and stability. Annu. Rev. Biochem. 2009, 78, 929-958. [CrossRef]

32. Bonifacio, A.; Sergo, V. Effects of sample orientation in Raman microspectroscopy of collagen fibers and their impact on the interpretation of the amide III band. Vib. Spectr. 2010, 53, 214-217. [CrossRef]

33. Vogel, A.; Venugopalan, V. Mechanisms of pulsed laser ablation of biological tissues. Chem. Rev. 2003, 103, 577-644. [CrossRef]

34. Improta, R.; Benzi, C.; Barone, V. Understanding the role of stereelectronic effects in determining collagen stability. I. A quantum mechanical study of proline, hydroxyproline, and fluoroproline dipeptide analogues in aqueous solution. J. Am. Chem. Soc. 2001, 123, 12568-12577. [CrossRef] [PubMed]

35. Carcamo, J.J.; Aliaga, A.E.; Clavijo, R.E.; Garrido, C.; Gomez-Jeria, J.S.; Campos-Vallette, M.M. Proline and hydroxyproline deposited on silver nanoparticles. A Raman, SERS and theoretical study. J. Raman Spectr. 2011, 439, 750-755. [CrossRef]

36. Overman, S.A.; Thomas, G.J., Jr. Amide modes of the $\alpha$-Helix:Raman Spectroscopy of Filamentous Virus fd containind peptide ${ }^{13} \mathrm{C}$ and ${ }^{2} \mathrm{H}$ labels in coat protein subunits. Biochemistry 1998, 37, 5654-5665. [CrossRef] [PubMed]

37. Gullekson, K.; Lucas, L.; Hewitt, K.; Kreplak, L. Surface sensitive Raman spectroscopy of collagen I fibrils. Biophys. J. 2011, 100, 1837-1845. [CrossRef] [PubMed]

38. Jenkins, C.L.; Bretscher, L.E.; Guzei, I.A.; Raines, R.T. Effect of 3-hydroxyproline residues on collagen stability. J. Am. Chem. Soc. 2003, 125, 5422-5427. [CrossRef] [PubMed]

39. Wisniewski, M.; Sionkowska, A.; Kaczmarek, H.; Lazare, S.; Tokarev, V.; Belin, C. Spectroscopic study of a KrF excimer laser treated surface of the thin collagen films. J. Photochem. Photobiol. A Chem. 2007, 188, 192-199. [CrossRef]

40. Renugopalakrishnan, V.; Carreira, L.A.; Collette, T.W.; Dobbs, J.C.; Chandraksasan, G.; Lord, R.C. Non-uniform triple helical structure in chick skin type I collagen on thermal denaturation: Raman spectroscopic study. Z. Naturforsch. 1998, 53, 383-388. [CrossRef]

41. Careche, M.; Herrero, A.M.; Rodriguez-Casado, A.; del Mazo, M.L.; Carmona, P. Structural changes of hake (Merluccius merluccius L.) fillets: Effects of freezing and frozen storage. J. Agric. Food Chem. 1998, 47, 952-959. [CrossRef]

42. Herreiro, A.M.; Carmona, P.; Careche, M. Raman spectroscopic study of structural changes in hake (Merluccius merluccius L.) muscle proteins during frozen storage. J. Agric. Food Chem. 2004, 52, 2147-2153. [CrossRef]

43. Herrero, A.M. Raman spectroscopy for monitoring protein structure in muscle food system. Crit. Rev. Food Sci. Nutr. 2008, 48, 512-523. [CrossRef]

44. Kumar, R.; Sripriya, R.; Kumar, M.S.; Sehgal, P.K. Physical characterization of succinylated type I collagen by Raman spectra and MALDI-TOF/MS and in vitro evaluation for biomedical application. J. Mol. Struct. 2011, 994, 117-124. [CrossRef]

45. Carcamo, J.J.; Aliaga, A.E.; Clavijo, R.E.; Branes, M.R.; Campos-Vallette, M.M. Raman study of the shockwave effect on collagens. Spectrochim. Acta Part. A. 2012, 86, 360-365. [CrossRef]

46. Czerniecka-Kubicka, A.; Neilsen, G.; Dickson, M.S.; Woodfield, B.F.; Janus-Kubiak, M.; Kubisz, L.; Zarzyka, I.; Zielecki, W.; Skotnicki, M.; Hojan-Jezierska, D.; et al. Vibrational heat capacity of silver carp collagen. Int. J. Biol. Macromol. 2020, 163, 833-841.

47. Kubisz, L.; Hojan-Jezierska, D. Application of in vivo electrical impedance measurement in human skin assessment. In Proceedings of the 1st International Conference on Chemistry for Beauty and Health, BEAUTY-TORUŃ, Torun, Poland, 13-16 June 2018.

48. Meyer, M. Processing of collagen based biomaterials and the resulting materials properties. Biomed. Eng. Online 2019, 18, 1-74. [CrossRef]

49. Sionkowska, A.; Lewandowska, K.; Adamiak, K. The Influence of UV Light on Rheological Properties of Collagen Extracted from Silver Carp Skin. Materials 2020, 13, 4453. [CrossRef]

50. Gauza-Włodarczyk, M.; Kubisz, L.; Włodarczyk, D. Amino acid composition in determination of collagen origin and assessment of physical factors effects. Int. J. Biol. Macromol. 2017, 104, 987-991. [CrossRef] [PubMed]

51. Wiliams, R.W.; Dunker, A.K. Determination of the secondary structure of proteins from the Amide I band of the laser Raman spectrum. J. Mol. Biol. 1981, 152, 783-813. [CrossRef]

52. Wiliams, R.W. Estimation of protein secondary structure from the laser Raman amide I spectrum. J. Mol. Biol. 1983, 166, 581-603. [CrossRef]

53. Alix, A.J.P.; Pedanou, G.; Berjot, M. Fast determination of the quantitative secondary structure of proteins by using some parameters of the Raman amide I band. J. Mol. Struct. 1988, 174, 159-164. [CrossRef]

54. Edwards, H.G.M.; Farwell, D.W.; Holder, J.M.; Lawson, E.E. Fourier-tranform Raman spectroscopy of ivory: II.Spectroscopic analysis and assignments. J. Mol. Str. 1997, 435, 49-58. [CrossRef]

55. Cai, S.; Singh, B.R. Identification of $\beta$-turn and random coil amide III infrared bands for secondary structure estimation of proteins. Biophys. Chem. 1999, 80, 7-20. [CrossRef] 
56. Ignatiewa, N.; Zakharkina, O.; Leroy, G.; Sobol, E.; Vorobiewa, N.; Mordon, S. Molecular processes and structural alterations in laser reshaping of cartilage. Laser Phys. Lett. 2007, 4, 749-753. [CrossRef]

57. Janko, M.; Davydovskaya, P.; Bauer, M.; Zink, A.; Stark, R.W. Anisotropic Raman scattering in collagen bundles. Optics Lett. 2010, 35, 2765-2767. [CrossRef] [PubMed]

58. Mandal, A.; Sekar, S.; Chandrasekaran, N.; Mukherjee, A.; Sastry, T.P. Vibrational spectroscopic investigation on interaction of sago starch capped silver nanoparticles with collagen: A comparative physicochemical study using FT-IR and FT-Raman techniques. RSC Adv. 2015, 5, 15763-15771. [CrossRef]

59. Knudsen, L.; Johansson, C.K.; Philipsen, P.A.; Gniadecka, M.; Wulf, H.C. Natural vibrations and reproducibility of in vivo near-infrared Fourier transform Raman spectroscopy of normal human skin. J. Raman Spectrosc. 2002, 33, 574-579. [CrossRef]

60. Fernandes, R.M.T.; Neto, R.G.C.; Paschoal, C.W.A.; Rohling, J.H.; Bezerra, C.W.B. Collagen films from swim bladders: Preparation method and properties. Colloids Surf. B Biointerfaces 2008, 62, 17-21. [CrossRef] [PubMed]

61. Safandowska, M.; Pietrucha, K. Effect of fish collagen modification on its thermal and rheological properties. Int. J. Biol. Macromol. 2013, 53, 32-37. [CrossRef]

62. Pietrucha, K.; Safandowska, M. Dialdehyde cellulose-crosslinked collagen and its physicochemical properties. Process. Biochem. 2015, 50, 2105-2111. [CrossRef] 